\title{
Identifying the Practice of Tattooing in Ancient Egypt and Nubia
}

\author{
Geoffrey J. Tassie \\ Institute of Archaeology, UCL
}

\begin{abstract}
Tattooing was practised by many ancient societies, including the ancient Egyptians and Nubians. Egypt, for example, boasts iconographic and physical evidence for tattooing for a period spanning at least 4000 years - the longest known history of tattooing in the world. The second oldest physical evidence for tattooing worldwide was recovered from Middle Kingdom contexts in Egypt and C-Group contexts in Nubia (the Hanslabjoch ice man being the oldest). It has been suggested that tattooing was also practised in the Predynastic period as evidenced by figurines with geometric designs, however, no physical evidence for tattooing has yet been found for this early period. Strangely there is almost no mention of tattooing in ancient Egyptian written records. Historical and ethnographic records indicate that tattooing was also practised much more recently in the Coptic, Islamic and modern eras. Unlike many past societies, tattooing in Egypt appears to have been a custom practised almost exclusively on women. Tattooing tools have not yet been positively identified from ancient Egypt. Ethnographic sources suggest that bundles of metal rods were used in Egypt's more recent history. This paper discusses physical and iconographic evidence for tattooing in ancient Egypt and investigates whether five copper rods found at Kafr Hassan Dawood, a Predynastic to Early Dynastic site in the East Delta, could be physical evidence for tattooing during this early period.
\end{abstract}

\section{Introduction}

The word 'tattoo' derives from the Tahitian word tatatau, which means 'to strike properly' and which Captain Cook recorded as 'tattow' (Hassan et al. 1991). In traditional societies, permanent body decoration has a psychological or practical purpose, or sometimes both. Sending out a range of social signals, body decoration plays an important part in expressing and reinforcing social relationships, values and society itself. As with temporary forms of body decoration, e.g. hairstyles, painting and make-up, permanent body decoration helps to define boundaries of social groups and sub-groups within society by marking differences in status and role. Their very permanence allows the latter forms of body decoration to perform tasks that the more transitory forms do not. Thus they demonstrate permanent social relationships between an individual and society. Permanent body decoration is often applied when an individual goes through a rite of passage and attains a new social status, such as adulthood (Rubin 1988). While the reasons for tattooing can change over time, the end result is still a permanent marking, an enculturalisation of the body.

The study of tattooing and enculturalisation of the body in past societies, and the recognition of ancient tattooing needles both on archaeological sites and in museums, have been only recently undertaken (Bianchi 1985, 1988, 1996; Hassan et al. 1991; Keimer 1948; Magor 1999; Rubin 1988). This paper examines the practise of tattooing in ancient Egypt and Nubia, and presents criteria for identifying possible tattooing needles in archaeological contexts. A holistic approach is used, utilising the available archaeological material including iconographic data, and comparing and contrasting this with ethnohistoric and ethnographic evidence from the region to provide possible 
parallels for ancient remains and practices. In this approach, cognitive, socio-religious and socio-sexual aspects are all incorporated into the analysis and interpretation of the evidence.

While the textual record from ancient Egypt makes no direct reference to the practice, it has long been recognised that the ancient Egyptians indeed tattooed themselves; there is much iconographic evidence, as well as a number of tattooed desiccated human remains. Winlock (1942: 74), for example, excavated tattooed mummies from Deir elBahari in 1922-23. However, the identification of actual tattooing needles has proved to be a difficult task; they have not yet been positively recognised in archaeological contexts - some may have been mislabelled as awls or sewing needles. The use of many artefacts can only be inferred from their context and association, and tattooing needles are no different, although, if found sufficiently well-preserved, scientific analysis of their tips may identify traces of blood or the pigment used to create the tattoo.

\section{Tattooing Methods and Tools}

Two methods appear to have been used in tattooing by traditional societies to introduce the pigment into the subcutaneous layers of skin: the sewing and the puncture methods. The sewing method is used to create lines; up to 40 stitches are used to make a line $5 \mathrm{~cm}$ in length. An eyed needle is used with a piece of twine or sinew blackened with soot. The needle is pulled through the skin in short but deep stitches, and pressure is applied to the skin with the thumb to rub in the pigment. The operation ends with oil

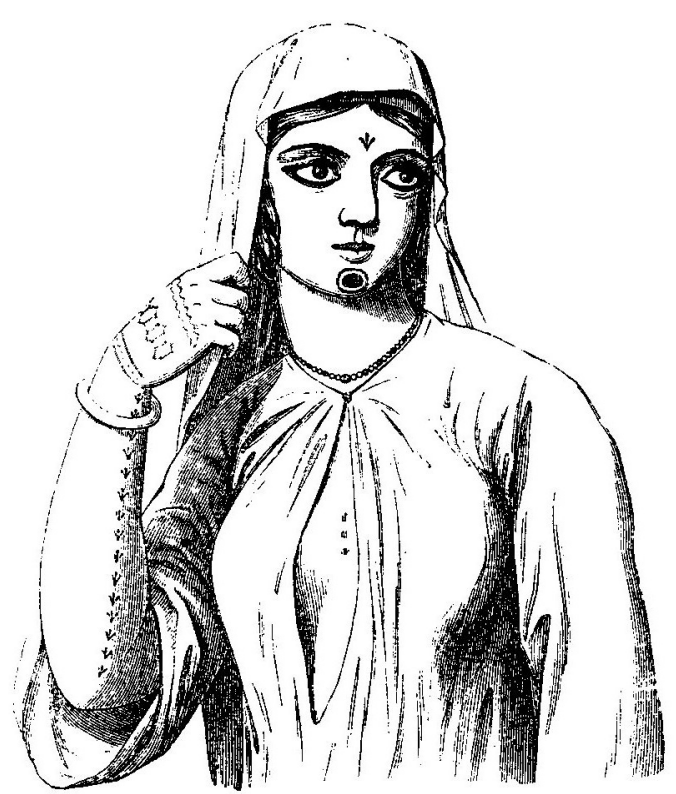

Figure 1. Edward Lane's drawing of a tattooed Egyptian woman from the early part of the $19^{\text {th }}$ century (from Lane 1860: 40). being rubbed into the skin (Hassan et al. 1991: 111-112). In contrast, the puncture method uses a sharp pointed instrument, such as a pin or needle to break the skin. Pigment may be applied to the tip of the needle or may be rubbed into the broken skin after being pricked. This method may be used to create dots, lines or figures, and appears to have been the method preferred for tattooing in ancient Egypt, judging from the patterns found on tattooed desiccated human remains.

Keimer (1948: 55-64), in his seminal work on the subject of tattooing in ancient Egypt, reviews many early travellers' accounts of tattooing in Egypt and elsewhere in Africa. The majority of these relate that an uneven number of metal needles tied together and hafted 
into a wooden handle were used. Wild (1623: 204) noted that Egyptian women would colour their hands and around their mouth with little blue dots, as if they had pricked themselves with needles and rubbed charcoal into the wounds. Edward Lane, during his stay in Egypt (1833-35), observed that some women of the lower orders tattooed their faces with blue designs, usually their chins and foreheads, and also the backs of their hands, their arms, feet and the middle of their bosom (Lane 1860: 39); simple dots, circles and lines were often used (Fig. 1). Tattooing may have been carried out on Egyptians, like many other Near Eastern and North African peoples as a rite of passage, and may have been used to ward off evil and disease (Myers 1903: 87). Tattoos may also have played a role in defining an individual and maintaining the continuity of social units and social relationships.

Blackman described the method of tattooing among the Fellahin of Upper Egypt and noted that:

...the implement used in tattooing consists of seven needles fixed into a short stick, which is bound round at the end and then plastered over to keep them firmly in position. Sometimes smaller needles, and only five in number, are used for tattooing children. Lamp-black [soot] is the pigment employed, and this is usually mixed with oil, though some people say that water is used.

(Blackman 1927: 51)

The designs were first drawn on the skin by the tattoo artist with needles, the skin was then pierced using the tattooing tool before the soot dye was rubbed in. Alternatively, the points of the tattooing needles could be dipped in the soot mixture, and when the needles pierced the skin the pigment was left deep in the dermis layer. The tattooed surface may or may not bleed, but will become swollen and scab over. Both indigo and soot have antiseptic properties helping to prevent infection, and herbs such as cloves or leaves of white beet could be applied after the tattooing was completed to reinforce the tattooed design and reduce the swelling (Lane 1860: 39-40; Smeaton 1937: 60). After three to seven days the scab will fall off leaving the tattoo fixed deep in the skin (Smeaton 1937: 60).

The Copts, who also used the puncture method, relate that the number of needles used to tattoo must be of an odd number, as these bring luck and are of good fortune. For the Copts, the number three represents the Holy Trinity, and this appears to be the reason why many Coptic tattoos consist of three lines, three dots and two elements (Caswell 1958; Keimer 1948: 59). Preference for specific numbers is also apparent in ancient Egyptian tattoos, which often consist of three, seven or nine rows of dots or lines, although groups of 6 and 16 were also sometimes encountered (Bianchi 1988). To the ancient Egyptians certain numbers held magical properties, such as two, three, seven and nine. Two symbolised duality and unity as in the 'Two Lands', while three symbolised plurality as in the triads or families of the gods. The number five, though not in itself symbolic, may have been valued because it is the sum of two (duality) and 
three (plurality). Likewise, the number seven, being the sum of three (plurality) and four (totality) may also have been attributed magical properties, as indicated by the seven sacred oils, the seven Hathors and the seven gates in the Duat, through which the deceased had to pass. Nine, made up of three threes, may have represented the concept of a great number, a plurality of plurals, because the Ennead of nine gods represented all the gods, and the Nine Bows symbolised all of Egypt's enemies (Clark 1960; Wilkinson 1999).

The preference for particular numbers of rows of dots or lines thus implies a reference to number symbolism, but also points to the number of strikes and tattooing needles used to make a particular tattoo. The dots and strokes on the mummified remains (see below) appear too large to have been applied with a single needle, indicating that they may have been applied by multiple needles. In addition to expressing number symbolism, tying the needles together in bundles would have increased the tensile strength of the object; also the more needles tied together the greater the area that can be covered in one strike. Outlining a tattoo was possibly done with fewer needles than infilling the design.

In modern Egypt, tattooing needles inserted into wooden handles are usually blind; they can therefore be described as awls. Awls can be used for a multitude of piercing purposes, such as piercing holes in leather. Objects usually referred to as metal, bone and stone 'awls', as well as 'sewing needles', have been found at numerous sites throughout Egypt and Nubia dating from the prehistoric to the modern era. However, some of these may have been used in tattooing. The piercing of human skin in tattooing would have probably been done with fine-tipped tools in order to create sharper designs and cause less bleeding. The strongest indicator that an 'awl' or 'sewing needle' was used for tattooing would be if charcoal and/or blood residues were found adhering to the tip. As most of the tools found have not been examined for these traces, they cannot conclusively be assigned a particular function, be it as 'sewing needles' or possibly as tattooing tools. However, evidence of pigments and carrying mediums on such implements in general is an area that needs further investigation.

\section{Human Remains: Tattooed Mummies from Egypt and Nubia}

In ancient Egypt there is no artistic or physical evidence that men were tattooed apart from one Dynasty XII stele from Abydos. This depicts a figure, which is said to be male, with marks coming down over the chest. As the stele is extremely worn it is hard to distinguish whether the marks indeed represent tattoos (Bianchi 1988, 1996; Keimer 1948). Thus, the vast majority of evidence (mummified human remains, dynastic figurines and tomb scenes) suggests that only women were tattooed in ancient Egypt (Bianchi 1988). In Nubia, originally only C-Group women were tattooed, but by the Meroitic Period both men and women were tattooed and scarified. The symbolic meaning of the practice of body modification thus appears to have been gendered and differed in both societies.

\section{Comparative Chronology of the Main Cultural Groupings of Egypt and Nubia}

Of the mummified remains found in Egypt and Nubia dating from the Middle Kingdom 
and C-Group periods (c.2000 BC) up to the Ptolemaic and Meroitic periods (c.300 BC) (Table 1), 42 female tattooed bodies and a much smaller number of male bodies (1+) have so far been found; the majority in Nubia (Bianchi 1988, 1996; Firth 1927; Fletcher 1997; Keimer 1948). The tattoos usually consist of dotted patterns, probably made with an uneven number of needles. Nubian mummies often come from simple round or oval pit graves with much of the desiccated bone and flesh having decayed or been disturbed. The Nubian examples of tattooed female mummies thus are often in a poorer state of preservation than the examples from Egypt.

\begin{tabular}{|l|l|l|}
\hline Date & Egypt & \\
\hline 5500 BC & $\begin{array}{l}\text { Predynastic (5500 - 3360 BC) } \\
\text { Faiyum A (5500 - 3800 BC) } \\
\text { Badarian (4500 - 3750 BC) }\end{array}$ & A-Group (3650 - 2950 BC) \\
\hline 4000 BC & $\begin{array}{l}\text { Naqada I (3900 - 3700 BC) } \\
\text { Naqada II (3700 - 3350 BC) } \\
\text { Protodynastic (3350 - 3150 BC) } \\
\text { Naqada III (3360 - 2700 BC) }\end{array}$ & Hubia \\
\hline 3000 BC & $\begin{array}{l}\text { Early Dynastic (3150 - 2613 BC) } \\
\text { (I Dyn. - III Dyn.) } \\
\text { Old Kingdom (2613 - 2181 BC) } \\
\text { (IV Dyn. - VI Dyn.) } \\
\text { First Intermediate (2181-2055 BC) } \\
\text { (VII Dyn. - XI Dyn.) }\end{array}$ & C-Group (2345 - 1500 BC) \\
\hline out?) & $\begin{array}{l}\text { Middle Kingdom (2055 - 1782 BC) } \\
\text { (XI Dyn. - XIV Dyn.) } \\
\text { Second Intermediate (1650 - 1550 BC) } \\
\text { (XV Dyn. - XVII Dyn.) } \\
\text { New Kingdom (1550 - 1069 BC) } \\
\text { (XVIII Dyn. - XX Dyn.) }\end{array}$ & Egyptian dominance of Nubia \\
(Kerma and Kush)
\end{tabular}

Table 1. Comparative chronology of the main cultural groupings of Egypt and Nubia.

\section{Mummies of the Early $2^{\text {nd }}$ Millennium BC}

Many of the tattooed bodies found in Nubia were excavated during two Nubian archaeological surveys. Firth (1927: 54), who was part of the first survey, reports of a female mummy in C-Group grave 271 in Cemetery 110 near the village of Quban (Kubban), now under the waters of Lake Nasser south of Aswan. The tattoo marks on the wellpreserved skin of her abdomen "...compare [to] the marks on the C-Group pottery dolls 
from Cemetery 87" (Firth 1927: 54). Many other mummies were found in the Nubian surveys with tattoos on their abdomens, chests, arms and legs (Keimer 1948: 16; Smith 1911: 56; Smith and Dawson 1924: 80; Steindorff 1935: 118-9). The excavators regularly reported the tattoos on the human remains as resembling the patterns found on figurines from the C-Group graves, some tattooed mummies even had tattooed figurines placed in the grave with them, suggesting that patterns on figurines are representations of tattoos. The C-Group is contemporaneous with the Egyptian Middle Kingdom.

The most famous tattooed bodies from Egypt are the Dynasty XI mummies found at Deir el-Bahari: Amunet, a Priestess of Hathor who also bore the title of 'King's Fa-

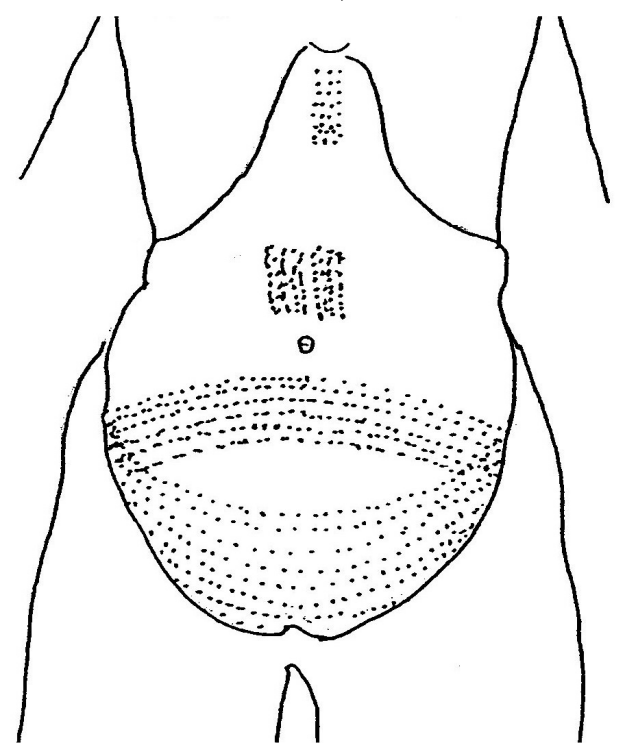

Figure 2. Detail of the abdominal tattoos visible on a Dynasty XI mummy of Amunet (re-drawn by Colette Standish, after Bianchi 1988, fig. 2; from Keimer 1948, fig. 9). vourite Ornament,' and two other mummies, found in Pits 23 and 26, who were described as Hathoric dancers in the court of King Mentuhotep II (Daressy 1893: 106; Winlock 1942, 1947). The mummy of Amunet is now in the Egyptian Museum of Antiquities, Cairo and the two Hathoric dancers in the Metropolitan Museum of Art, New York. The mummy of Amunet was first discovered by Grébaut in 1891 (Daressy 1913: 99100; Fouquet 1899: 207) near the Temple of Mentuhotep II at Deir el-Bahari in her own tomb in a wooden coffin; the other coffin in the tomb was found to contain bovine bones. The mummy was well preserved, with bead necklaces and a menat collar still in place around her neck, with rings on her fingers and bracelets on her arms beneath her bandages. On her left shoulder and breast is a tattoo consisting of a row of dots encased in two lines. On her right arm below the elbow there are many rows (approximately nine) of dotted tattoo marks. There may be corresponding marks on the left arm, but these are not visible as the mummy is lying on her left side. The tattoos on her stomach are in two groups (Fig. 2) making an elliptical pattern of dots and dashes, just above the navel and below the chest. Those just above the navel region consist of seven to nine rows of nine strokes in a rectangular pattern. Another tattoo on the medial line, at the top of the epigastric basin, consists of six lines made up of three dashes each. There is also a large rectangular tattoo made up of rows of little lines virtually covering the whole of the abdominal wall in the suprapubic region. Another tattoo is located in the middle of the right thigh in the design of multiple diamond shapes; again this design is composed of dots. All of the tattoos appear dark blue in colour (Keimer 1948: 9-13). In the area of the groin there is also evidence of scarification in the form of three horizontal parallel lines. 
The 1923 Metropolitan Museum of Art Expedition to Deir el-Bahari led by Winlock, excavated two mummies from Pits 23 and 26, located very near the tomb of Amunet (Winlock 1942, 1947). These mummies were found to have tattoos on their bodies: dotted lozenge shapes were placed across their chests, arms and legs, on the dorsum of their feet and across their abdominal regions. The positioning of the tattoo designs is similar for both mummies. The lozenge designs are made up of 16 dots, and several lozenges form patterns that run across the abdomen and around the upper arms and thighs, both inside and out, and down the chest (Keimer 1948: 8-9). Tattoos on the abdominal part of the female body would have become particularly notable when the woman became pregnant - the patterns would expand, forming an even more symbolically interesting pattern, like a web or netting design. It is possible that such extensive sets of tattoos may not have been applied all at once, and may have taken several years for the full set to be completed, possibly marking life events, as occurs in many societies (Rubin 1988; Smeaton 1937).

\section{Mummies of the $1^{\text {st }}$ Millennium BC}

Tattoos similar to those found on the C-Group mummies were also found on later mummies of both adolescent and adult women, which were recovered in excavations at Aksha, a Meroitic site dating to the fourth century BC located just south of Abu Simbel and Faras (Vila 1967). The mummies showed dark blue tattoos in similar positions to those found on the Nubian C-Group, but also with facial and hand tattoos (Bianchi 1988: 23; Seguenny 1984: 151; Vila 1967: 370-7). No male mummies from Nubia have been identified with abdominal or thigh tattoos, however, at least one male mummy has been identified with facial tattoos, with other bodies being unsexed (Vila 1967: 370). Blue facial tattoo marks are also characteristic of some of the bodies from other Meroitic cemeteries in Nubia (Shinnie 1967: 155).

Several tattooed mummies have been found dating to the Ptolemaic Period in Egypt, which is contemporary with the Meroitic Period in Nubia. The tattoos are usually dotted patterns on the face and hands. However, these types of tattoos may show Greek and Persian influences mixed with indigenous Nilotic traditions. Although the designs on the face are not of Greek origin, the concept of facial tattooing seems to have been part of Greek and Persian penal tattooing tradition (Jones 1987; Magor 1999), and seems not to have been practised in the Nile Valley during the C-Group or Middle Kingdom. However, facial tattooing is also found in Nubia on Meroitic Period mummies and could possibly have been introduced into Egypt during Dynasty XXV when Egypt was ruled by Nubian kings; the results of the third Nubian rescue campaign currently taking place in the region of the Fourth Cataract may help prove or disprove this theory. Roman Period mummies found by Maspero at Akhmim also have tattoos on their chin and side of the nose (Strouhal 1992: 88-9). Although no mummified remains can be posited as having religious tattoos, it is possible that a New Kingdom tattooing practice may have lived on into the Ptolemaic Period with certain Egyptians tattooing religious symbols on themselves, especially on the wrists and arms (Jones 1987: 144; Keimer 1948: 44, 53). This tattooing practice may have influenced the early Coptic Christians in their tattooing traditions, with many of the later Coptic tattoos being very similar to those of the the Graeco-Roman era (Jones 1987: 145). 


\section{Origins}

As human remains with evidence of tattooing have not been identified in Egypt before the Middle Kingdom, the origin of Egyptian tattooing has frequently been attributed to Nubian influences, in particular the C-group (Bianchi 1988), with which Egypt at this period was having greater contact through Egypt's imperial expansion down to the Second Cataract. Indeed, a Nubian origin for some of the Egyptian mummies has been suggested. In Derry's correspondence to Winlock, he suggests that the two mummies Winlock found in pits 23 and 26 may have been of Nubian descent; paintings of some of these Hathoric dancers, on their sarcophagi show them dressed as Egyptians but with dark Nubian skin colouring (Naville 1907, 1910; Winlock 1942: 129-30). Although Winlock does not publish Derry's letter, another letter from Derry is reproduced in Keimer (1948: 14-5), and although Derry does not mention the Nubian origin of the two mummies from Pits 23 and 26, he makes an analogy between the ancient mummified remains and modern Sudanese body modification traditions. A fragment of a relief from the tomb of Amunet was found by Naville (1907: pl. XVII, B) in his excavations of the Mentuhotep II Temple at Deir el-Bahari. This fragment shows Amunet with typical Egyptian eye make-up, wearing a short round Egyptian hairstyle and typical Egyptian necklaces; however, her ethnic origins as depicted by her skin colour are unclear in the black and white photograph. Possibly she is painted in a tawny orange colour, as she does not seem to be of the typical dark brown the Egyptians painted Nubians, or the light yellow reserved for depictions of elite Egyptian women.

Although the Hathoric dancers of the Middle Kingdom may have had some Nubian origins, they could have been born in Egypt and been thoroughly Egyptian in their ideology, manners and customs. It is impossible to tell in which region the tattoos were applied to them and the ethnic origin of the tattoo artists. Thus, the evidence does not allow a conclusive identification of the Deir el-Bahari mummies as either Egyptians or Nubians. The apportioning of the origin of the tattooing tradition to either of the two regions is very equivocal, considering the great mobility between Lower Nubia and Upper Egypt throughout the Predynastic and Pharaonic periods and especially in view of the fact that many Nubians either lived in Egypt or were under Egyptian political control living in Nubia, particularly from the Middle Kingdom when Egypt annexed Lower Nubia through to the end of the New Kingdom (Smith 2003).

The scarcity of well-preserved early mummies makes the identification of tattooing on the basis of human remains before the Middle Kingdom problematic. The majority of the preserved mummified remains in both Egypt and Nubia are from the later periods. Although natural mummies occur, the art of mummification with evisceration was only in its infancy in the Old Kingdom, developing further in the Middle Kingdom and New Kingdom. Therefore, few mummies have survived from the periods prior to the Middle Kingdom (Ikram and Dodson 1998: 108-130). Formal mummification was also a practice originally restricted to royalty and the elite. From the Middle Kingdom, mummification became available to a wider spectrum of the population, becoming even more widely available in the Ptolemaic and Meroitic periods, but with variable quality (Ikram and Dodson 1998). Therefore, it is usually iconographic material that is put forward as evidence of tattooing when there is a lack of mummified remains. 
Because the mummified remains indicate that tattooing was practised in both Egypt and Nubia by c.2000 BC, and Egypt was a cosmopolitan nation from the Predynastic onwards, it may be more appropriate to view tattooing as part of a single Nile Valley body modification tradition with ideas and innovations flowing back and forth between the two regions. However, the fact that more mummified remains with tattoos dating to early periods come from the most northerly part of Lower Nubia, an area known as and settled by the Wawat tribe, it may be that they developed the practice of tattooing to culturally identify themselves from the Egyptian civilisation to the north and the growing Kerma (Kushite) civilisation to the south in Upper Nubia (Smith 2003). The flow of this tradition into Egypt seems almost immediate, and was taken up by some Egyptian women who then modified this tradition into iconographic motifs such as Bes.

It seems that the tattooing of women in Middle Kingdom Egypt and in the C-Group and Meroitic periods in Nubia may have indicated physiological changes, reproductive capacity and sexuality, whereas, the Bes tattoos, which were originally a magico-religious New Kingdom Egyptian practice, seem more concerned with protection during childbirth (see below). The same cannot be said of Meroitic men's tattoos from Nubia, which appear to be placed only on their hands and face, and may be more about social relationships than physiological changes and reproductive capacity. The origin of tattooing in Graeco-Roman Egypt is questionable, with the possible exception of magicoreligious tattoos, and therefore does not form part of this study (see Jones 1987).

\section{Iconographic Evidence: Figurines with Possible Tattooing Patterns Egyptian Figurines Found in Egypt}

As no actual evidence has been found of tattooing in examinations of Predynastic human remains, or on extant mummies from the Old Kingdom, no definitive conclusions can be drawn as to whether the designs on Predynastic figurines actually represent tattoos (Bianchi 1988: 21; Smith 1923: 63). However, patterns of lines and dots on some female Egyptian Predynastic figurines have been interpreted by some scholars as the earliest evidence of tattooing on the female body (Hornblower 1929: 28; Keimer 1948: 181; Thevoz 1984: 62-3). Not all Predynastic figures have patterns of lines and dots; indeed, many have no decoration at all, while others show geometric patterns or even zoomorphic figures. Many of these designs are very similar to those found on crosslined vessels dating to Naqada I, Petrie's seriation SD 31-34. On many of the vessels, the geometric and animal designs draw attention to musculature, movement and motion, showing zigzags, parallel lines, spirals and chevrons adjacent to the zoomorphic figures (Magor 1999: 57).

There are many examples of footless faience figurines dating primarily to the Middle Kingdom, which usually depict a woman in the nude or wearing just a cowrie shell girdle and bead necklace, although some types depict a simple patterned sheath dress. The nude figurines usually have an elaborate long hairstyle, often in the Hathoric manner, with two large curls over their breasts, whereas the figurines wearing dresses usually have a short round hairstyle. Some have been found in domestic contexts, others in tombs. The context of some figurines which were found in domestic altars ".... relates them to this specific group of images concerned with family continuity" (Robins 1996: 
30), while those found in tombs were to aid and safeguard rebirth into the next life. These faience figurines often display patterns that have been interpreted as tattoos on the abdomen and arms. Lozenge shapes made up of dots or lines on the legs are especially prominent. A faience figurine from the Brooklyn Museum of Art (cat. no. 44.226) is shown nude and with a Hathoric hairstyle. On her body is a series of dots, many in lozenge-shaped patterns. There is one horizontal line of dots just above her pubic triangle, which may represent tattoos (contra Bianchi 1988: 22, who sees the pattern as invoking a cicatrix). A faience figurine of a dancing girl with a cowrie shell girdle was found in the tomb of Neferhotep the Bowman, and was depicted as being tattooed exactly like the mummies of the two dancers found at Deir el-Bahari (Winlock 1942: 74).

Middle Kingdom paddle dolls, spatula-like shaped wooden figures with roughly shaped arms, frequently depict tattoos of Taweret. This hippopotamus-headed goddess was portrayed with a lion's arms and legs and a crocodile's back and tail; she was a protector of women, especially during childbirth. The heads of paddle dolls are defined by a thin neck and a large hairstyle made of strings of little mud-balls, and occasionally eyes are painted on the face. These dolls are without legs but often show the female genitals, even when wearing a dress. In addition to the anatomical details drawn on these dolls in red and black, there were often zoomorphic and geomorphic patterns, and in some instances these appear to represent tattoos. Some paddle dolls have lozenge shapes painted on them consisting of 16 dots, similar to the tattoos on the mummies of dancers from Deir el-Bahari. The lozenges are placed on the shoulders or arms, or in place of or near the painted genitalia, as exemplified by Cairo Museum cat. no. 43088a. Often, an image of Taweret is placed by the genitals on the dolls (e.g. Cairo Museum cat. no. 43088b) (Keimer 1948: pl. XV-XVII). Crocodile tattoos can also be shown in this protective position, near the genitalia, on Middle Kingdom paddle dolls.

\section{Egyptian Figurines Found in Egyptian Nubia}

In the New Kingdom, in addition to the traditional tattoos, images of the protective deity Bes start to be tattooed at the top of one or both thighs, a position traditionally occupied in the Middle Kingdom by Taweret. In the Philadelphia Museum of Art there are two wooden statues of naked women (cat. no. 10349), originally found in a tomb in the Egyptian town of Buhen, Nubia. They hold a fruit or flower in one hand, the other hand hanging by their side. They are adorned with bouffant gala hairstyles, necklaces, bracelets, cowrie shell girdles, and at the top of each thigh is depicted a tattoo of Bes (Keimer 1948: 42).

\section{Nubian Figurines Found in Egypt}

A bronze mirror handle, currently in the Brooklyn Museum of Art (cat. no. 66.27.1), in the shape of a young Nubian woman shows each thigh tattooed with the image of Bes (Bianchi 1988: 25)

\section{Bes Figures}

That figures of Bes were indeed tattooed on the thighs of women in ancient Egypt (albeit at a later period) is supported by the finding of a tattoo of Bes on the thigh of a female 
mummy from Aksha in Nubia, dating to the fourth century BC (Vila 1967: 373). The blue-black image is rather abstract, and executed in the puncture method (Vila 1967).

Bes, like Taweret, is a protective deity during childbirth and has been found carved on beds and bedroom walls, on cosmetic containers and amulets. He is thought to have evolved from a leonine deity of the Predynastic Period, and was the tutelary deity of revelry and unbridled cavorting, which was the reason he was thought to preside at childbirth (Romano 1982: 223-224). The tattooing of Bes has therefore been seen as an encouragement to indulge in carnal fulfilment, and the wearers of such tattoos have previously been interpreted as being prostitutes wearing such charms for protection from venereal disease (Schumann-Antelme and Rossini 2001: 68). A review of the evidence, however, does not support this theory. The interpretive association of Bes tattoos with prostitution is a theory originating in the Victorian era when some $19^{\text {th }}$ century criminologists, following the positivist theory of the day, expounded the view that men who mutilated their skin by tattooing indicated a mad, bad or perverted character. This was considered the prerogative of the uneducated and criminal classes, and that a tattooed woman must therefore be a prostitute (Fletcher 1997). This parochial Victorian view of tattooing reflects that of the Classical World which actually marked the criminals and slaves of the day with facial tattoos (Magor 1999). The disapproval by the Christian church of body decoration in general has also done much to degrade the practice of tattooing, putting it amongst ungodly activities (Barnard 1996: 51; Jones 1987: 144).

All pictorial representations of Bes tattoos have been found on either dancers or musicians from the latter part of Dynasty XVIII until the end of the New Kingdom, and although they are depicted nude, this in itself is not an indicator of prostitution. Dancers and musicians were not synonymous with prostitutes in Egypt. Dancers and musical troupes could be attached to royal, religious and private households; music and dance was associated with Hathor the goddess of sexuality and love (Robins 1993). Wall paintings in tomb chapels of the elite depict nude girls in scenes of daily life, such as banquet scenes, serving drinks and entertaining the guests who are fully clothed, however this "mode of representation was not used to depict named formal figures but is rather a generic image used to portray female dancers, musicians, and servants" (Robins 1996: 30). As the formal female figures are never shown nude, it cannot be ascertained whether or not they were tattooed. Naked adolescent girls and other symbols of fertility often decorated cosmetic items such as spoons and jars and formed the handles of mirrors, which were closely associated with Hathor (Robins 1996). These naked girls can be seen as representing female sexuality and fertility, which is in accord with their use as decoration on beauty items, which were later interred in the tomb, and also served as tomb decoration, as "in all the contexts in which this motif appears it is in association with, or as a substitute for, items that carry references to fertility, birth, and rebirth, or to Hathor, who presided over these" (Robins 1996: 33).

Bes, through his association with fertility and reproduction, is also associated with Hathor. However, because Bes is associated more strongly with protection during childbirth and new mothers, it would be most probable that women had a tattoo of Bes on their thigh to protect them from disease and complication in childbirth, as the death 
rate in childbirth proved very high for both mother and child. The association of the birthing gods with naked women, especially those with children, suggests that the rituals performed at the household altar decorated with scenes of Bes or Taweret were concerned with female fertility, protection during childbirth and the child itself, and continuity of the family (Robins 1996). This does not exclude the sexual nature of music and dance or of Bes, but the placement of the tattoo and Bes' principal function would seem to indicate its primary symbolic role as being that of protection and secondarily of sexuality. One of the most impressive examples of a Bes tattoo is found on the thigh of a lute player (a possible Priestess of Hathor due to the triple plait on the crown of her tripartite hairstyle), depicted on a New Kingdom faience bowl now in the Leiden Rijksmuseum van Oudbeden (cat. no. AD 14) (Bianchi 1988: 25). A naked dancer is shown with a dark blue tattoo of Bes on each thigh on a fragment of a Dynasty XIX wall painting found at the Workmen's Village at Deir el-Medina (Vandier d'Abbadie 1938: pl. III). Initially, the secular context of this painting was stressed (Vandier d'Abbadie 1938), however, the fresco originally decorated a wall to which a bench-like structure was attached, which has been interpreted as either a shrine or as a bed to give birth on (Bierbrier 1982). Thus, tattooing predominantly of women, and the positioning of some tattoos, such as dot-dash designs, as well as Bes and earlier Taweret figures, on the thighs and/or the abdomen, strongly indicate that the tattooing practice was closely linked to female spheres of life, and indicate their possible protective functions to aid fertility or to protect the wearer from death in childbirth.

\section{Criteria for Identifying Ancient Egyptian Tattooing Needles}

Tattooing was practised in ancient Egypt and Nubia since at least the Middle Kingdom and the C-Group as suggested by iconographic depictions and tattooed human remains. How can Egyptian and Nubian tattooing needles be identified in an archaeological context? The salient points from the above study are:

- Traces of blood or pigment on the tips of the needles.

- $\quad$ Blind metal fine-tipped awls or needles, often tied together or set in a handle in uneven numbers, normally between three and seven.

- $\quad$ Gender specificity, at least in Egypt, with the association of the needles with women, such as in female cosmetic items.

It may not be possible to apply all criteria to a single find, but the above list provides standard criteria for the recognition and identification of tattooing needles in ancient Egypt beyond mere speculation. The uneven numbering of tattooing needles - seemingly following ancient number symbolism - appears as important for the identification of tattooing tools as their shape. Context, it seems, is a further important factor in the identification of tattooing needles. The identification of traces of pigment and/or blood on the tips of the tools may be the most secure indicator. However, this is often prevented by the poor state of preservation of such types of finds. 


\section{Case Study: Possible Ancient Egyptian Tattooing Needles}

Having reviewed the art of tattooing in ancient Egypt and Nubia, and established criteria for identifying tattooing needles in archaeological contexts, these can now be tested against tools that have been suggested as being tattooing needles. The earliest example of a suggested tattooing needle found in Egypt dates to late Dynasty I. Petrie (1901: 24) found a microlith set in a wooden stick in the royal tombs at Abydos, and he concluded that this implement was probably used for creating tattoos. However, Bianchi (1985: 146) dismisses Petrie's argument without further explanation, and suggests that the tattooing instruments used by the ancient Egyptians consisted of between one and three fish bones set in a handle. He does not provide an extant example. However, the Abydos instrument is very similar to examples used by some traditional societies (as mentioned above). In these cases the point is held against the skin and lightly tapped, and the pigment is then introduced. No conclusive evidence of pigmentation or blood on the tip of this instrument is available.

Bronze needles found by Petrie at Gurob in 1880 (Thomas 1981), dating to Dynasty XII, and now kept at the Petrie Museum of Egyptian Archaeology, UCL (cat. no. UC 7790), have been tentatively identified as tattooing needles (Booth 2001; Thomas 1981). Petrie (1917: 51) originally described these needles as prick points for removing thorns, due to their similarity to later Graeco-Roman prick points found in thorn-removing sets. These bronze needles are in the form of flat rectilinear pins ranging from $34-51 \mathrm{~mm}$ in length, with the tips folded over to form a point. Seven examples were found, three tied together and four separately, the fourth of which also showed signs of a thread being attached to it (Booth 2001; Petrie 1917). Booth identified these as pins primarily due to their association with cosmetic items and fine pottery ware, and their apparent specialised function (Booth 2001: 14). However, Booth neither utilises the many ethnohistoric descriptions of the act of tattooing in Egypt, nor does she consult Bianchi (1985, 1988, 1996), the leading modern authority on ancient Egyptian tattooing. Although Booth presupposes the use of these metal rods, and produces very little evidence in support of this deduction, her conclusion is not necessarily wrong. That seven metal rods were found together associated with cosmetic items is a compelling argument, given the criteria for tattooing needles set out above. However, most tattooing needles used by traditional societies are more needle or awl-like (Keimer 1948; Bianchi 1988, 1996), rather than flat. Additionally, the uneven lengths and the lack of sharpness of the points make these examples unsuitable as tattooing needles. Therefore, the use of these tools must still be in question.

During the 1998/9 field season at Kafr Hassan Dawood (KHD), a Late Predynastic to Early Dynastic cemetery site (c.3200 BC) in the East Delta of Egypt (Hassan 2000; Hassan et al. in press), five metal rods or awls were discovered (Fig. 3 and inset), the context and association of which may indicate their use as tattooing needles. The five metal rods were found in Grave 1027, a disturbed, multiple burial that lay partly beneath and was cut by Grave 1015, a secondary multiple inhumation. The osteological material from Grave 1027 was examined by Teri L. Tucker (Washington State University) and Simon Hillson (UCL), who identified the skeletal remains of two individuals, a male and a female both aged 25-35 years. The highest elevation in the northern part of the burial was heavily disturbed; however, the southeastern portion of the grave which 
contained the post-cranial articulated skeletal remains of the female burial were undisturbed. The skeleton was in the flexed position lying on its right side, oriented eastwest with head west, facing south. The grave goods included two fine-ware pots: one small bowl and a larger ceramic jar with a potmark. Several other goods were found in the southeastern part of the grave, associated with the undisturbed portion of the female inhumation. The five metal rods (find no. 3075), measuring approximately $75 \mathrm{~mm}$ in length and $2 \mathrm{~mm}$ in diameter, were found compacted together in apparent association with four flint blades (find nos. 3062-65) between the female's tibia and fibula. Other grave items included small beads of semi-precious stones.

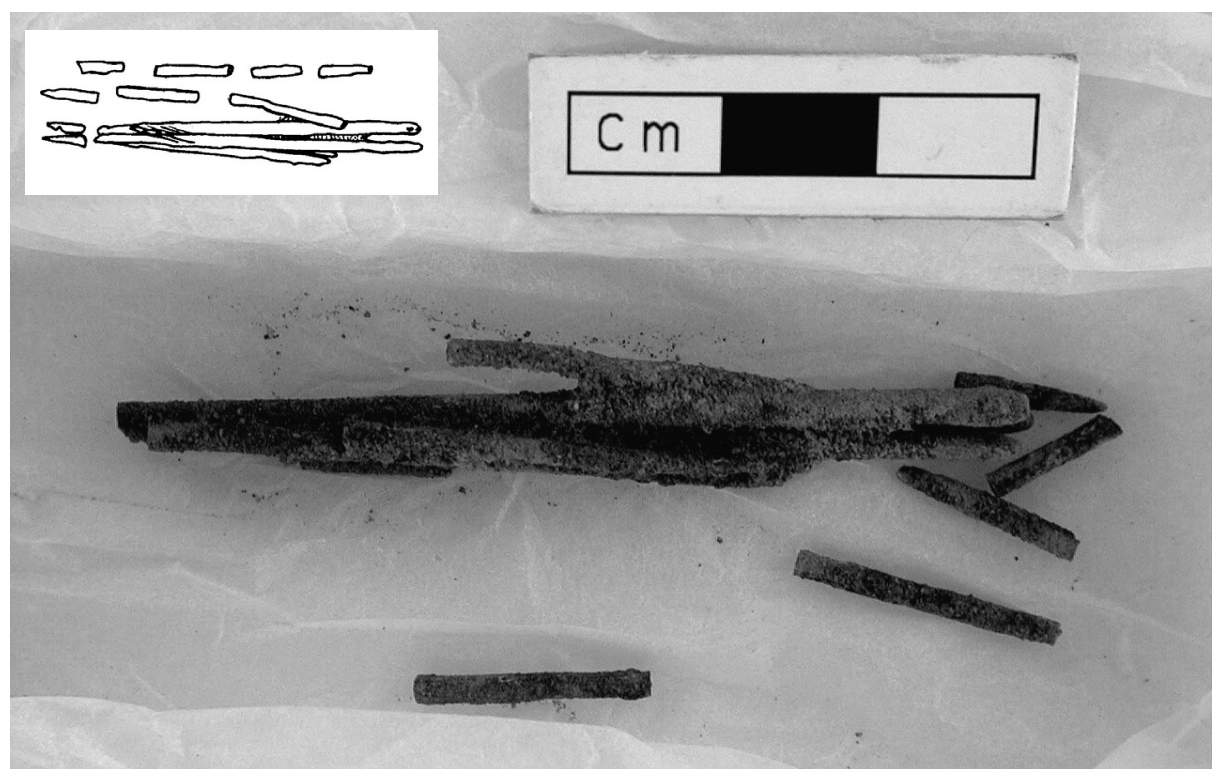

Figure 3. The metal rods excavated form KHD, find no. 3075 (photograph Joris van Wetering; inset drawing by Serena Langousa not to scale).

The metal rods appear to be corroded and are brittle and extensively broken. There were three differently-styled hemispherical heads amongst the five metal rods, which all tapered to a point at the other end: one was eyed, another had a notch and the three remaining ones were plain. Some surface areas were covered by preserved organic remains which appeared to be associated with the rods, and may have consisted of a reed or rush-like material into which at least three of the rods were inserted or wrapped, and with which they appeared to be tied together. Amanda Sutherland (English Heritage and KHD archaeological conservator) examined the five metal rods under 10x magnification. The nature of the corrosion products was unusual in structure and colour, the cross-section being composed of compacted blackish-grey crystalline corrosion retaining the original surface, covered by hard dark green corrosion products. Quantitative analysis revealed the metal to be composed of virtually pure copper. At KHD it is unlikely that any organic residues (i.e. those of the carrying medium such as oils, fats or waxes) would have survived the strongly alkaline burial conditions and remain adhered 
to the points of the metal rods. Likewise any traces of charcoal or pigment used to create the tattoos are likely to have been washed away during burial.

These artefacts could have been used as a leather working set, with the eyed needle used for sewing, the lithic blades used for cutting and the three awls used for piercing. The notched awl may have been used as a crochet hook, possibly for making fine mesh netting. However, because of their shape, association, number and context, the rods could also be identified as tattooing needles. The association of the metal awls with the female burial of Grave 1027, and the fact that at least three appear to have been tied together and associated with the lithic blades (which may also have been used in tattooing), seems to indicate their possible use as tattooing needles. That there were five needles is also indicative of a tattooing set; that one of them has an eye and another a notch may simply indicate re-use of an object. Traces of pigmnent and/or blood on the tips of the needles could put the question of use beyond doubt; unfortunately, such traces are not preserved at KHD.

\section{Conclusion}

From at least 2000 BC, evidence indicates that Nubian and Egyptian women were tattooed. These tattoos seem to have been primarily concerned with anxiety about fertility, as well as protection during childbirth, and were also linked with Hathor and therefore, sex, love, music and dance. Although there has been much discussion as to whether or not the Predynastic Egyptians practised tattooing, no physical evidence has been recovered, and it was left to scholars to give their various interpretations of the patterns on Predynastic figurines (Bianchi 1988, 1996; Fletcher 1997; Hornblower 1929; Keimer 1948; Petrie and Quibell 1896; Smith 1911); most concluded that the geometric designs on Predynastic figurines did not constitute conclusive evidence of tattooing. However, the discovery of three tattooed mummies at Deir el-Bahari seems to provide physical evidence demonstrating that tattooing took place in ancient Egypt in Dynasty XI - if the mummies are accepted to be culturally Egyptian rather than Nubian women. The identification of tattooing needles in archaeological contexts would help to provide a fuller picture of this practice. However, if the evidence for tattooing needles, as argued here, is indeed as much a matter of context as of form, then many tattooing needles may have been overlooked in past archaeological investigations. Some of the many awls and needles found on archaeological sites may in fact have been used as tattooing needles. Although the metal rods found at KHD are not unequivocal proof of Predynastic tattooing needles, criteria for identifying tattooing needles have been now put forward.

\section{Acknowledgements}

I would like to acknowledge the help of Prof. F. A. Hassan (KHD Director), and the whole team of archaeologists at KHD, especially Joanne M. Rowland, for their insights and scientific knowledge, and also express my appreciation to Janet M. Johnstone and Jack Green for imparting certain information to me. 


\section{References}

Barnard, M. 1996. Fashion as Communication. Hassan, F. A. 2000. Kafr Hassan Dawood. Egyptian Routledge: London. Archaeology 16, 37-9.

Bianchi, R. S. 1985. Tatowierung. Lexicon Hassan, F. A., Tassie, G. J., Tucker, T. L., Rowland, Äegyptische 6, 146. J. M. and van Wetering, J. F. L. in press. Social Dynamics at the Late Predynastic

Bianchi, R. S. 1988. Tattoo in Ancient Egypt, in Rubin, A. (ed.) Marks of Civilization: Artistic Transformation of the Human Body. Los Angeles: Museum of Cul- Hassan, J. P. H., Meldgaard, J. and Nordqvist, J. tural History, University of California, 1991. The Greenland Mummies. Lon21-28. don: British Museum Press.

Bianchi, R. S. 1996. Tattooing and Skin Painting in Hornblower, G. D. 1929. Predynastic Figures of the Ancient Nile Valley, in Celenko, T. (ed.) Egypt in Africa. Indianapolis: Indianapolis University Press, 81-83.

Bierbrier, M. 1982. The Tomb Builders of the Pharaohs. London: British Museum Press. Women and Their Successors. Journal of Egyptian Archaeology 15, 35-47.

Ikram, S. and Dodson, A. 1998. The Mummy in Ancient Egypt. London: Thames and Hudson.

Blackman, W. S. 1927. The Fellahin of Upper Egypt. London: G. G. Harrap and Co.

Jones, C. P. 1987. Stigma: Tattooing and Branding in Graeco-Roman Antiquity. The Journal of Roman Studies 77, 139-155.

Booth, C. 2001. Possible Tattooing Instruments in the Petrie Museum. Journal of Egyptian Keimer, L. 1948. Remarques sur le Tatouage dans Archaeology 87, 172-175, pl. XXXVIII, l'Égypte Ancienne, Memoires Presentés à l'Institut D'Égypte vol. 53. Le Caire: L'institut Français d'Archéologie Orientale.

Carswell, J. 1958. Coptic Tattoo Designs. Beirut: Faculty of Arts and Science, American University of Beirut.

Lane, E. W. 1860 [1973]. An Account of the Manners and Customs of the Modern Egyptians, $5^{\text {th }}$ edition. London: Dover Publications.

Clark, R. T. R. 1960. Myth and Symbol in Ancient Egypt. London: Thames and Hudson.

Magor, A. 1999. People Illustrated. Archaeology 2, 54-57. de Travaux Relatifs à la Philologie et à l'Archéologie Égyptiennes et Asyriennes 14, 166-8.

Myers, C. S. 1903. Contributions to Egyptian Anthropology No. 1. Tattooing. Journal of the Anthropological Institute of Great Britain and Ireland 33, 82-89.

Daressy, G. 1913. Les Rois Mentouhotep. Sphinx 17, 97-109.

Naville, E. 1907. The XIth Dynasty Temple at Deir el Bahari, pt. 1. Memoir 28. London: Egypt Exploration Fund. bia: Report for 1910-11. Cairo: National Print Dept.

Naville, E. 1910. The XIth Dynasty Temple at Deir el Bahari, pt. 2. Memoir 30. London: Egypt Exploration Fund. tooed Mummies of Ancient Egypt. Nile Offerings: 1.

Petrie, W. M. F. 1901. The Royal Tombs of the Earliest Dynasties. Memoir 30. London: Egypt Exploration Fund, Archaeological Survey of Egypt. dans l'Antiquite et à l'Époque Actuell. Archives d'Anthropologie Criminalle $13,1-10,270$ 
Petrie, W. M. F. 1917. Tools and Weapons. London: Smith, G. E. and Dawson, W. R. 1924. Egyptian British School of Archaeology in Egypt, University College London. Mummies, London: G. Allen and Unwin.

Petrie, W. M. F. and Quibell, J. E. 1896. Naqada and Smith, S. T. 2003. Wretched Kush: Ethnic Identities Ballas. London: Bernard Quartich. and Boundaries in Egypt's Nubian Empire. New York: Routledge.

Robins, G. 1993. Women in Ancient Egypt. London: British Museum Press.

Steindorff, G. 1935. Aniba, Vol 1. Cairo: Service des Antiquitiés de l'Égypte - Mission Archéologique de Nubia, 1929-1934/ Hamburg: Druck von J. J. Augustin. tation of Fertility and Potency in New Kingdom Art, in Kampen, N. B. (ed.) Sexuality in Ancient Art. Cambridge: Strouhal, E. 1992. Life in Ancient Egypt. London: Cambridge University Press, 27-40. Opus.

Romano, J. F. 1982. Egypt's Golden Age: The Art of Thomas, A. P. 1981. Gurob, a New Kingdom Town: Living in the New Kingdom 1558-1085 B.C., Exhibition Catalogue. Boston: Museum of Fine Arts Boston. Introduction and Catalogue of Objects in the Petrie Museum. Warminster: Aris and Phillips.

Rubin, A. (ed.) 1988. Marks of Civilization: Artistic Thevoz, M. 1984. The Illusion of Reality: The PaintTransformation of the Human Body. Los Angeles: Museum of Cultural History, University of California. ed Body. New York: Skira/Rizzoli.

Vandier d'Abbadie, J. 1938. Une Fresque Civile de Deir el-Médineh. Revue d'Egyptologie $3,27-35$.

Schumann-Antelme, R. and Rossini, S. 2001. Sacred Sexuality in Ancient Egypt (trans. Graham, J.). Rochester: Inner Traditions.

Vila, A. 1967. Aksha II: Le Cimétière Meroïtique d'Aksha. Paris: Librairie Klincksiek.

Seguenny, E. 1984. Quelques Eléments de la Religion Populaire de Soudan Ancien, in Hintze, F. (ed.) Meriotistische Forshungen 1980. Meroitica 7. Berlin: AkademicVerlag, 149-155.

Shinnie, P. L. 1967. Meroe: A Civilization of the Sudan. London: Thames and Hudson.

Smeaton, W. 1937. Tattooing Among the Arabs of Iraq. American Anthropologist 39, 53-61.

Smith, G. E. 1911. The Ancient Egyptians and Their Influence upon the Civilizations of Europe. London: G. Allen and Unwin.

Smith, G. E. 1923. The Ancient Egyptians and the Origins of Civilization. London: G. Allen and Unwin.

Winlock, H. E. 1947. The Rise and Fall of the Middle Kingdom at Thebes. New York: Macmillan.

Wild, J. 1623. Neue Reysbeschreibung eines Gefangenen Chriśten Anno 1604.. Nuremberg: Steingrüben.

Wilkinson, R. H. 1999. Symbol and Magic in Egyptian Art. London: Thames and Hudson.

Winlock, H. E. 1942. Excavations at Deir el-Bahri, 1911-1931. New York: Macmillan. 